\title{
Infância ou infâncias?
}

\section{Resumo}

Ao estudarmos infância, devemos ter em mente que a infância pode ser analisada sob diferentes perspectivas. Ao longo do tempo, diferentes conceitos de infância vêm sendo elaborados. Este artigo tem como objetivo desvelar a infância sob a ótica de historiadores, higienistas e pesquisadores em sociologia da infância. Inicialmente, discutiremos a infância sob a perspectiva histórica. A seguir, abordaremos a concepção higienista em relação à infância, desvelando a história da Pediatria no Brasil, no final do século XIX e primórdios do século XX. A seguir, abordaremos a infância à luz da sociologia.

Palavras-chave: Infância. Pediatria. História. Sociologia.

\author{
Adriza Santos Silva Barbosa \\ Universidade Estadual do \\ Sudoeste da Bahia - UESB - \\ Brasil \\ adrizabarbosa@gmail.com \\ João Diógenes Ferreira dos \\ Santos \\ Universidade Estadual do \\ Sudoeste da Bahia - UESB - \\ Brasil \\ jdiogenes69@gmail.com
}

\section{Para citar este artigo:}

BARBOSA, Adriza Santos Silva; DOS SANTOS, João Diógenes Ferreira. Infância ou infâncias?. Revista Linhas.

Florianópolis, v. 18, n. 38, p. 245-263, set./dez. 2017. 


\title{
Childhood or Childhoods?
}

\begin{abstract}
In studying childhood, we must bear in mind that childhood can be analyzed on different perspectives. Over time, different concepts of childhood have been developed. This article aims to reveal the childhood from the perspective of historians, hygienists and childhood sociology researchers. Initially, we will discuss childhood in the historical perspective. Next, we design the hygienist in relation to childhood, revealing the history of Pediatrics in Brazil, in the late nineteenth century and early twentieth century. Next, we childhood in the light of sociology.
\end{abstract}

Keywords: Childhood. Pediatrics. History. Sociology. 


\section{Introdução}

Por albergar diversas concepções, a infância não se prende a um só significado. Ao longo do tempo, diferentes conceitos de infância vêm sendo construídos. Ainda assim, dentro de cada perspectiva abordada, poderemos encontrar várias “infâncias".

Tal pluralidade deve ser levada em consideração não só pelos pesquisadores em infância, mas também por profissionais que lidam com crianças. Com esse objetivo, pretendemos abordar, neste artigo, algumas das concepções de infância, especificamente sob a ótica dos historiadores, dos higienistas (perspectiva biológica) e dos pesquisadores em sociologia da infância.

\section{Infância: perspectiva histórica}

Considerando a criança como também sendo um ser social, o conceito de infância se insere na trajetória histórica (FURLANETTO, 2008). Segundo Sarmento (2005, p. 365366):

A infância é historicamente construída, a partir de um processo de longa duração que lhe atribuiu um estatuto social e que elaborou as bases ideológicas, normativas e referenciais do seu lugar na sociedade. Esse processo, para além de tenso e internamente contraditório, não se esgotou. [...] A geração da infância está, por consequência, num processo contínuo de mudança, não apenas pela entrada e saída dos seus actores concretos, mas por efeito conjugado das acções internas e externas dos factores que a constroem e das dimensões de que se compõe.

Com base nas obras "História Social da Criança e da Família", de Phillip Ariès, e "História das Crianças no Brasil”, de Mary Del Priore, descreveremos as concepções de infância construídas em diferentes épocas, sendo, no primeiro caso, a infância retratada na Europa e no segundo caso, no Brasil. Escolhemos estas obras por serem consideradas "tradicionais" para os pesquisadores em infância. Todavia, ressaltamos que elas não devem ser consideradas como incontestáveis ou representações fidedignas do passado.

Segundo Ariès (2012), até meados do século XII, não havia diferenciação entre crianças e adultos na arte medieval. Elas eram representadas, apenas, "numa escala mais 
reduzida que os adultos, sem nenhuma diferença de expressão ou de traços" (ARIÈS, 2012, p. 17). Da arte para a vida real, Ariès (2012) conclui que a infância, neste período, era constituída de transitoriedade, pois compreendia a fase da criança de colo, totalmente dependente do cuidado dos outros para sobreviver. Assim que adquiria algum grau de independência, já passava a pertencer ao mundo dos adultos. Segundo o autor, na Idade Média as crianças não apresentavam distinção dos adultos quanto à vestimenta, à participação na vida social e no lazer.

A partir do século XVI, surgiu o hábito de retratar as crianças que morriam. Naquela época, a mortalidade infantil era elevada, ou seja, perdiam-se, com frequência, as crianças numa fase bem precoce da vida. Por esse motivo, não havia um sentimento de apego àquele ser frágil. Era uma insensibilidade que, para Ariès (2012), era comum nas condições de vida da época. "As pessoas não se podiam apegar muito a algo que era considerado uma perda eventual" (ARIÈS, 2012, p. 22).

Logo, retratar as crianças que faleciam reflete uma mudança nos sentimentos em relação à infância:

O gosto novo pelo retrato indicava que as crianças começavam a sair do anonimato em que sua pouca possibilidade de sobreviver as mantinha. É notável, de fato, que nessa época de desperdício demográfico uma criança morta, a fim de conservar sua lembrança. O retrato da criança morta, particularmente, prova que essa criança não era mais tão geralmente considerada como uma perda inevitável. (ARIES, 2012, p. 23)

Entretanto, foi no século XVII que a criança passou a ser retratada sozinha, representando a si própria, em suas atividades cotidianas ou com a sua família. Outro fator foi a adoção de um traje próprio para a criança, em especial pelas classes socioeconomicamente favorecidas ${ }^{1}$. Atitudes estas que demonstram um sentimento da sociedade em separar a criança do mundo dos adultos.

Ariès (2012) descreve dois sentimentos que surgiram em relação à infância na sociedade entre a Idade Média e Renascença. O primeiro foi o de "paparicação". A criança era vista como um ser ingênuo, gracioso, que servia para distrair o adulto,

\footnotetext{
${ }^{1}$ Ariès salienta que as crianças das classes menos favorecidas continuaram a usar o mesmo traje dos adultos. "Elas conservaram o antigo modo de vida que não separava as crianças dos adultos, nem através do traje, nem através do trabalho, nem através dos jogos e brincadeiras" (ARIES, 2012, p. 41). Tem-se, portanto, num mesmo momento, diferentes infâncias.
} 
podendo ser comparada a um animal de estimação. Paralelamente, surgia, por parte dos moralistas, uma crítica a este sentimento. A criança era um ser puro e frágil, mas era necessário moldá-la, através da disciplina, para que se tornasse um adulto honrado.

Na Renascença, manifesta-se, portanto, a preocupação em preparar a criança para o convívio social, sendo os jesuítas, no Brasil, os principais responsáveis em educar as crianças dessa época.

Em razão de sua vivência apostólica e da própria descoberta da infância, os padres entenderam que era sobre as crianças, essa "cera branda", que deviam imprimir-se os caracteres da fé e virtude cristãs. Para isso, elaboraram estratégias e projetos, que se transformavam à medida que se consolidava a própria conquista portuguesa na América, e que seguiam os ventos que traziam e enviavam suas cartas ao Velho Mundo. (CHAMBOULEYRON, 2013, p. 79)

Indubitavelmente, a obra de Philippe Ariès é pioneira em estudos sobre a infância, leitura obrigatória para o pesquisador deste tema. No entanto, a sua obra não é isenta de críticas $^{2}$, sendo uma delas, a de que fontes utilizadas por Ariès para a sua pesquisa provêm de cartas, diários, pinturas e retratos da época. Tais elementos, majoritariamente, pertenciam a famílias da aristocracia. Nas palavras de Klein (2012, p. 13), “Ariès toma essa classe - que é formada por uma fração minoritária - como representação legítima da totalidade social". Esta autora ressalta, em seu artigo, a dura realidade das famílias da classe operárias e as condições adversas em que viviam as crianças trabalhadoras.

Em contraposição ao modelo idealizado de Ariès, é esta outra criança, capturada pela fábrica, objeto da violência sistemática do capital, que obriga a sociedade a pensar sobre ela. Essa preocupação emerge no processo social de luta pelas leis fabris, fulcradas na proibição do trabalho de crianças menores de 8 anos, na proibição de trabalho noturno de adolescentes e mulheres e diminuição da jornada de trabalho (inicialmente, para crianças, depois para adultos). É esse debate, que se impõe a toda a sociedade europeia ao longo do século XIX, que torna presente uma preocupação específica com as crianças, fazendo com que essa categoria se consolide no universo discursivo com um conteúdo historicamente dado, vale dizer, com o conteúdo das lutas fabris. Desdenhar esse fato histórico é construir ilusões que inviabilizam uma compreensão mais objetiva da condição de crianças e adolescentes na sociedade contemporânea. (KLEIN, 2012, p. 18)

\footnotetext{
${ }^{2}$ Sugerimos a leitura da obra de Moysés Kuhlmann Jr., Infância e Educação Infantil, uma abordagem histórica, na qual o autor nos leva a uma outra dimensão de infância, diferente do que propõe Ariès.
} 
Na coletânea organizada por Mary del Priore (2013), por sua vez, são retratadas diversas infâncias em diferentes momentos da história do Brasil. Tal diversidade pode ser constatada, especialmente no Brasil Colonial. Neste período, as concepções de criança variaram de acordo com a sua etnia e a sua condição de classe.

O entendimento de infância, proposto por Ariès, foi adotado, também, pelo Brasil Colônia. No entanto, tal concepção é reservada, como já referido anteriormente, apenas para a criança branca da elite (SANTOS, 2007). Geralmente essa criança permanecia sob os cuidados da mãe e amas, até aos sete anos de vida. A partir dessa idade, os meninos iam para as escolas, onde terminavam os estudos, "com um diploma de doutor, geralmente de advogado" (MAUAD, 2013, p. 152). Outra opção era seguir a carreira militar. A educação das meninas também se iniciava aos sete anos, mas era uma instrução mais voltada em transformá-las em donas de casa prendadas.

Aos meninos, uma educação voltada para o desenvolvimento de uma postura viril e poderosa, aliada a uma instrução, civil ou militar, que lhe permitisse adquirir conhecimentos amplos e variados, garantindo-lhe 0 desenvolvimento pleno da capacidade intelectual. [...] Por outro lado, a educação das meninas, padecia de ambiguidade, pois ao mesmo tempo que as circunscrevia no universo doméstico, incentivando-lhes a maternidade e estabelecendo o lar como seu domínio, as habilitava para a vida mundana, fornecendo-lhes elementos para brilhar em sociedade. (MAUAD, 2013, p. 155)

Já as crianças escravas, por sua vez, recebiam outro tratamento. Até chegar aos seis anos, os filhos de escravos usufruíam de alguma liberdade na casa grande, desfrutando de certa "igualdade familiar", como sublinha Goés e Florentino (2013). No entanto, a partir dos sete anos, ou até antes, começavam a desempenhar atividades leves. Aos catorze anos, já realizavam as mesmas atividades dos escravos adultos (GOÉS; FLORENTINO, 2013).

Era uma infância que já se iniciava com dificuldade. Segundo Goés e Florentino (2013), poucas crianças conseguiam chegar à fase adulta: “os escravos com menos de dez anos de idade correspondiam a um terço dos cativos falecidos; dentre estes, dois terços morriam antes de completar um ano de idade, $80 \%$ até os cinco anos" (GOÉS; 
FLORENTINO, 2013, p. 180). Aqueles que subsistiam, viviam uma infância de humilhações, servindo de brinquedos humanos para os meninos da elite.

Ao crescer, o menino branco recebe como companheiro de brincadeiras um curumim indígena e depois um muleque negro que para tudo serve: de amigo, de cavalo de montaria, de burro de liteira, de carro de cavalo em que um barbante serve de rédea e um galho de goiabeira, de chicote. Eram os "manés-gostosos", os leva pancadas. (ALTMAN, 2013, p. 243, grifo do autor)

As crianças brancas, imersas em um meio onde o castigo aos escravos era visto com naturalidade, absorviam tendências sádicas e reproduziam o tratamento cruel que os pais dispensavam aos escravos nos muleques. Altman (2013) descreve que não era raro ocorrerem suicídios de crianças negras, diante dessa situação.

Por outro lado, a criança indígena era vista com ambiguidade pelos padres jesuítas, pois, ao mesmo tempo em que entendiam que os curumins eram filhos de "selvagens" que "viviam em pecado", eles acreditavam que essa criança deveria ser educada e civilizada a fim de se tornar uma pessoa apta para o trabalho (SANTOS, 2007).

Outra categoria de crianças, neste período, foi a de crianças brancas "enjeitadas", seja por serem oriundas de famílias pobres, que não tinham condições de sustentá-las, seja por serem frutos de relações extraconjugais. Abandonadas à própria sorte, a taxa de mortalidade dessas crianças era muito elevada (SANTOS, 2007).

Ainda segundo o autor, na tentativa de conter o elevado índice de abandono infantil, no século XVIII, o governo instala a Roda dos Expostos, um local onde as pessoas “depositavam" os “enjeitados" para serem "cuidados" pelas Santas Casas de Misericórdia. Ainda assim, a mortalidade era alta. As crianças do sexo masculino que conseguiam sobreviver, em torno dos 7-12 anos, eram encaminhadas para o trabalho, seja como aprendizes de ofícios, seja como grumetes ${ }^{3}$. As crianças do sexo feminino eram encaminhadas para instituições próprias para órfãs, onde aprendiam prendas domésticas.

\footnotetext{
3 Segundo Ramos (2013), os grumetes eram meninos entre nove e dezesseis anos, geralmente órfãos e desabrigados, ou provenientes de famílias de baixa renda, que serviam nas embarcações lusitanas. Essas crianças, em alto-mar, estavam expostas a condições precárias de vida (fome, fadiga, doenças), bem como eram submetidas a constantes abusos sexuais.
} 
Segundo Passetti (2013), com a proclamação da República, surge uma preocupação com a criança abandonada ou proveniente de "famílias desestruturadas". Difundia-se a ideia de que era preciso educar e "moldar" aquela criança para que não viesse a se tornar um delinquente. Para isso, foram criadas políticas públicas sociais designadas para este perfil de criança.

Uma história de internações para crianças e jovens provenientes das classes sociais mais baixas, caracterizados como abandonados e delinqüentes pelo saber filantrópico privado e governamental elaborado, entre outros, por médicos, juízes, promotores, advogados, psicólogos, padres, pastores, assistentes sociais, sociólogos e economistas -, deve ser anotada como parte da história da caridade com os pobres e a intenção de integrá-los à vida normalizada. Mas também deve ser registrada como componente da história contemporânea da crueldade. (PASSETTI, 2013, p. 350)

As políticas de internação para crianças abandonadas e infratoras, segundo Passetti (2013), eram regidas pelo medo, impessoalidade e rotinas rígidas. Era de se esperar que, submissas a esse regime, as crianças fossem disciplinadas com sucesso. Entretanto, em tal ambiente, predominava a corrupção e a ilegalidade.

O mundo dos prisioneiros não existe como algo separado ou marginal, ele se comunica com o mundo dos cidadãos livres por meio das ilegalidades, interceptações e exclusões. Forma e aprimora corruptores, enganadores e camufladores de ambos os lados. E obtém como resposta eficaz do prisioneiro ao cárcere, o investimento na sua destruição. Ele é o único que sabe e expressa que a prisão e o internato em vez de corrigir, deforma; que a integração se dá pelo avesso na ilegalidade; que a austera vida de interno orientada pela rotina que mortifica individualidades os dispõe enfileirados para ações delinquenciais. (PASSETTI, 2013, p. 356)

Na concepção moderna de infância, persiste a ideia de que as crianças são consideradas seres diferenciados, incapacitados, incompletos, que necessitam ser instruídos e socializados pelos adultos. Utilizando-se de conceitos de Foucault, sintetiza Sarmento:

a construção simbólica da infância na modernidade desenvolveu-se em torno de processos de disciplinação da infância [...], que são inerentes à criação da ordem social dominante e assentaram em modos de "administração simbólica", com a imposição de modos paternalistas de 
organização social e de regulação dos cotidianos, o desapossamento de modos de intervenção e a desqualificação da voz das crianças na configuração dos seus mundos de vida e a colonização adultocentrada dos modos de expressão e de pensamento das crianças. (SARMENTO, 2005, p. 369-370)

Com esse intuito, no início do século XX, leis e algumas políticas públicas foram criadas com a finalidade de assistir e educar os chamados menores ${ }^{4}$ : Código de Menores de 1927, Serviço Social de Menores Abandonados e Delinquentes (1938), Serviço de Assistência a Menores (1941), Recolhimento Provisório de Menores (1954), Fundação Nacional do Bem-Estar do Menor (1964), Código de Menores de 1979 e, finalmente, o Estatuto da Criança e do Adolescente, em 1990 (Passetti, 2013). Paradoxalmente, as últimas décadas do século XX transformam a concepção da infância em "sujeito de direitos" (FURLANETTO, 2008). É importante salientar que tal mudança se deve ao fruto das lutas de diversos movimentos sociais, ligados às mulheres, crianças e aos trabalhadores, em geral (LOPES, MEDES, FARIA, 2005).

Se, na teoria, tais direitos se estendem a todas as crianças, na prática, observamos que a criança negra e pobre, que antes era escrava, se torna menor e a criança branca, das classes média e alta, permanece sendo criança. Sendo assim, o Estatuto da Criança e do Adolescente ${ }^{5}$ concede direitos à criança e punições ao menor. Ontem e hoje, infâncias diversas e contraditórias (SANTOS, 2007).

\footnotetext{
4 Segundo Passetti (2013, p. 363), os menores são "crianças e jovens infratores ou abandonados, provenientes das situações de pobreza", "pequenos bandidos", "pobres e perigosos".

${ }^{5}$ Segundo Santos (2007, p. 183-185), "as diversas tentativas dos movimentos sociais, no decorrer das décadas de 70 e 80 , em explicitar os conflitos, emergidos da 'questão social', combater a exploração e o regime militar, bem como engendrar as noções de cidadania e de direitos - nascidas no processo de mobilização -, possibilitaram a criação do Estatuto da Criança e do Adolescente [...] O Estatuto trata dos direitos sociais universais, como saúde, cultura, esporte, profissionalização, moradia, alimentação, lazer e educação, e é dirigido a todas as crianças e adolescentes, sem exclusão. E assinala as políticas de proteção especial para as crianças e para os adolescentes em situação de risco pessoal e social. Também determina as medidas socioeducativas, destinadas aos jovens (12 a 18 anos) em conflitos com a lei."
} 


\section{A infância sob a ótica do saber médico}

Para compreender a concepção de infância sob o âmbito do saber médico, tornase necessário compreender as mudanças que ocorreram na sociedade ocidental, entre os séculos XIX e XX.

A consolidação do capitalismo, do Estado Moderno e do espaço privado foram alguns dos fatores que levaram a uma mudança, contribuíram na evolução do olhar da sociedade e, consequentemente, da Medicina sobre a criança, culminando com o surgimento da Pediatria (RIVORÊDO, 1998).

Martins (2008) descreve que, entre os séculos XVIII e XIX, aflora, nas famílias economicamente mais prósperas, um novo sentimento pelas crianças. Tal preocupação pode ser constatada em documentos da época, tais como cartas, pinturas, na literatura e, sobretudo, em textos médicos. Martins (2008, p.138) destaca ainda que

O hábito de chamar o médico para atender nas casas das famílias mais abastadas foi se tornando comum a partir do final do século XVIII na Europa, assim como a entrada dos médicos na cena do parto. A aproximação entre médicos e mulheres, a princípio bastante restrita às classes altas, possibilitou maior conhecimento sobre a gravidez, o parto, os primeiros cuidados com o recém-nascido e as doenças infantis, ampliando a confiança das mulheres nos médicos não só para atendê-las, mas também para com seus filhos pequenos.

Numa reflexão interessante, Rivorêdo (1998) destaca que esse novo olhar sobre a criança foi constituído de ambiguidade. De um lado, um sentimento de preocupação, o que levou a construção de práticas que assegurassem uma maior sobrevida às crianças. Por outro lado, surge um outro olhar sobre a infância. Além de cuidadas, as crianças deveriam também ser "moldadas" para serem aptas, futuramente, a se integrar na sociedade dos adultos. Aos adultos, os seres já completamente "formados", cabia a incumbência de disciplinar os seres incompletos, em formação:

Este é o mundo do cidadão, daquele que conta e comanda; daquele que domina. O mundo infantil é exatamente o seu oposto: fugaz e provisório, incompleto, apaixonado e irracional, dependente e submisso, indisciplinado e não-socializado, ou seja, o mundo do não-cidadão, daquele que vale pelo vir-a-ser através da socialização que, por sua vez é 
determinada pelas expectativas que o mundo do adulto configura para a criança... (RIVORÊDO, 1998, p. 36)

Nesse processo, a medicina se une ao Estado e a outros segmentos sociais (educadores, moralistas); é neste contexto que surge a Pediatria. Diferente de outras especialidades médicas, a pediatria não era voltada apenas para um determinado aparelho ou sistema do corpo humano, mas se atenta, de modo integral, para um indivíduo que se encontra em crescimento e desenvolvimento, envolto em singularidade e complexidade, cujo funcionamento é diferente do corpo adulto (PEREIRA, 2006).

Trata-se de uma especialidade que opera em duas frentes de atuação: a Pediatria Curativa ou Clínica Pediátrica, que trata da criança enferma, e a Puericultura, que se concentra na prevenção, ou melhor,

com ênfase no crescimento e no desenvolvimento, promoção da saúde e prevenção de agravos, considerando a criança como uma individualidade biopsicossocial e relacionando-a ao ambiente físico (biótico e abiótico) e psicossocial que a cerca. (MARCONDES, 2002, p. 117)

No início do século XX, o pensamento corrente era de que o Estado deveria intervir para que a criança se tornasse, futuramente, um cidadão instruído, saudável e apto para contribuir com o progresso da nação (SOUSA; OLIVEIRA, 2012). Entretanto, os altos índices de mortalidade infantil contrastavam com a aspiração de um Estado moderno e civilizado. Nesse contexto, surge a aliança entre Medicina e Estado, com o intuito de desenvolver ações que assistissem e protegessem as crianças, visando convertê-las, no futuro, em adultos civilizados. Essa convergência tipifica a Pediatria Social que, para Marcondes (2002, p. 117), "é a via final de todas as atividades de Puericultura e da Pediatria Clínica, é o compromisso de todos que assistem à criança e o adolescente com o seu universo."

A pediatria nasce, portanto, do pensamento higienista ${ }^{6}$, de que crianças e adultos deveriam receber tratamentos diferentes. Segundo essa perspectiva, a criança era

\footnotetext{
${ }^{6}$ Conforme Góis Júnior (2002), o movimento higienista surgiu entre o fim do século XIX e início do XX, sendo um pensamento oriundo das classes dirigentes (elites). Tinha como proposta cuidar, educar e ensinar novos hábitos à população, com o intuito de melhorar as condições de saúde coletiva. Segundo Challoub (1996, p. 29), “os intelectuais-médicos (...) analisavam a 'realidade', faziam seus diagnósticos,
} 
constituída de fragilidade, cujo organismo funcionava de maneira mais complexa, distinta dos adultos (SOUSA; OLIVEIRA, 2012).

Representada durante um longo período de nossa história enquanto mera cópia do adulto, apenas distinta a peso e estatura, o menino que não era "gente", tornou-se "gente". "Gente", porque começou a ser compreendido como diferente, como singular, como peculiar. Definida, essa singularidade, pelos dizeres da Pediatria nascente, tendo como base sua fisionomia e fisiologia. Da medicalização à alimentação, da higiene do corpo à educação, o médico foi tomando para si o monopólio à intervenção do corpo infantil. Pautado nos preceitos científicos, os quais validavam sua prática entre os pares, o médico-pediatra orientava a sociedade e, sobretudo a mãe no fino trato dos rebentos, acarretando a difusão do conhecimento por ele produzido. (SOUSA; OLIVEIRA, 2012, p. 10-11)

Atualmente, ainda permanece a ideia da criança frágil, revestida de incompletude, sendo comparada a uma semente, cujo germinar dependerá do solo e da maneira como será cultivada, cabendo ao pediatra salvar a criança dos flagelos socioambientais. Como exemplo, temos o livro "Pediatria Básica”, sob a organização de Eduardo Marcondes (2002). Este é um dos livros clássicos da Pediatria, sendo, frequentemente, utilizados pelos estudantes de Medicina e médicos pediatras. Em um trecho do primeiro capítulo, escrito por Pedro de Alcântara, evidencia-se o pensamento pediátrico acerca da criança:

Por tudo que vimos (a falta de treino de numerosas funções, antes de nascer, e a necessidade de pô-las em exercício e de modo coordenado depois de nascer), em cada um daqueles setores de dificuldades, a criança é mais vulnerável do que os adultos. Estes são, precisamente, as "ex-crianças" que, por melhores condições congênitas e por melhor assistência, venceram aquelas dificuldades e atingiram a idade adulta. Aquela maior vulnerabilidade se revela na mortalidade mais elevada de crianças do que de adultos, maior ainda no primeiro ano, maior ainda no primeiro mês, e só ultrapassada pela da velhice extrema, quando morrem todos. A vulnerabilidade maior da criança dá a assistência a esta um novo caráter, o de ser vigilante. (ALCÂNTARA, 2002, p. 3, grifo do autor)

O professor e médico pediatra Pedro de Alcântara (1901-1979) foi um dos fundadores da Escola Paulista de Medicina, em 1933, formando várias gerações de

prescreviam a cura, e estavam sempre inabalavelmente convencidos de que só a sua receita poderia salvar o paciente". Desta forma, os médicos ganharam autoridade para disseminar medidas que combatessem as condições que causassem danos à saúde da população (Góis Júnior, 2002). 
pediatras. Dedicou-se a estudar a relação entre a saúde da criança e as condições socioeconômicas da população e constatou que a mortalidade infantil se relacionava às mazelas sociais, como a pobreza, desnutrição e carência de atendimento médico, principalmente em áreas mais remotas. As suas ideias, portanto, perduram até hoje entre o meio acadêmico. ${ }^{7}$

Rivorêdo (1998) faz uma crítica a esse modo de pensar sobre a infância. Para ele, tanto a Medicina quanto a Pediatria se convertem em um instrumento que desqualifica a criança, transformando-a num sujeito incompleto, e ainda, num corpo/doença, perdendo de vista a totalidade e especificidade deste ser.

Saindo de uma perspectiva biológica, discutiremos, a seguir, a concepção de criança como ser social, sendo percebida de diferentes formas, ao longo da história.

\section{Infância: perspectiva sociológica}

De um ser que ocupava um espaço periférico na comunidade, a criança se torna, no final do século XX, alvo de estudiosos que desejam compreender melhor o seu papel na sociedade. Surge, então, a Sociologia da Infância ${ }^{8}$, em meados da década de 80 , num contexto em que as crianças deixam de ser vistas como sujeitos passivos na sociedade e passam a ser concebidas como "atores sociais" (DIAS, 2012). Tais atores são compreendidos como pertencentes a grupos sociais específicos (ex: gênero, classe social, etc.), sendo pesquisados em suas relações intra e intergeracionais (MARTINS FILHO; PRADO, 2011).

A Sociologia da Infância se propõe a resgatar a infância da perspectiva psicobiológica, que tende a uniformizar as crianças e seu desenvolvimento, deixando de lado o contexto sociocultural no qual estão inseridas. Outro objetivo da Sociologia da

\footnotetext{
${ }^{7}$ Estas informações podem ser vistas no site da Sociedade Brasileira de Pediatria (ver Referências).

${ }^{8}$ Segundo Mayall (2007 apud Delgado, 2011), podem ser caracterizadas três correntes na Sociologia da Infância: a sociologia das crianças, a construção social da infância e a sociologia estrutural da infância. No primeiro caso, as crianças são reconhecidas como atores sociais, ou seja, nas pesquisas, as crianças são escutadas. No segundo caso, é focalizada a diversidade da definição de infância no tempo e no espaço, sendo uma corrente mais voltada para os historiadores. Já no terceiro caso, a infância é concebida como uma categoria estrutural permanente, ou seja, se constitui como um segmento da sociedade, e o objetivo, nesta corrente, é o de estudar como os acontecimentos macro-históricos irão impactar as crianças (Qvortrup 1999 apud Delgado, 2011).
} 
Infância é estudar sobre a criança, a partir da própria criança, evitando a interferência do olhar adultocêntrico na pesquisa (SARMENTO, 2005).

Dessa maneira, repensando as teorias da socialização, percebemos que a criança passou de um lugar passivo para um lugar ativo; de um grupo silenciado para um grupo presente e contribuinte da sociedade em geral. E o fato de a infância ser contextualizada pelas ciências sociais, deixando de ser compreendida como fase universal e biológica da vida humana, desencadeou uma série de rupturas paradigmáticas no interior da Sociologia. (DIAS, 2012, p. 69)

William Corsaro (2011), um dos principais pesquisadores da Sociologia da Infância, critica o termo "socialização", preferindo utilizar o termo "reprodução interpretativa". Segundo este autor, o termo socialização tem uma "conotação individualista e progressista" (CORSARO, 2011, p. 31), implicando em "etapa de preparação para a vida adulta" (DIAS, 2012, p. 68). Para Corsaro, as crianças não imitam simplesmente o que captam do mundo adulto, mas se apropriam

criativamente da informação do mundo adulto para produzir a sua própria cultura de pares. Tal apropriação é criativa na medida em que tanto expande a cultura de pares (transforma a informação do mundo adulto de acordo com as preocupações do mundo dos pares) como simultaneamente contribui para a reprodução da cultura adulta. (CORSARO, 2002, p. 114)

Desta forma, a socialização não seria um processo linear, no qual as crianças internalizariam o mundo "externo" dos adultos, mas, na interação com outras crianças (seus pares), elas também se tornam parte da "cultura adulta". Utilizando o brincar, o "faz-de-conta", elas reproduzem o que experimentam na vida real, avançando e recuando "da cultura dos adultos para a cultura de pares" (CORSARO, 2002, p. 121). Seria uma forma de interpretar o mundo dos adultos. Gradualmente, elas vão adquirindo “conhecimento e competências necessárias para participar no mundo adulto" (CORSARO, 2002, p. 114).

Outro aspecto apontado pelo autor é o de que a criança sofre influência da sociedade, na qual está integrada. O autor alega que existem diferentes infâncias e 
demonstra essa concepção ao pesquisar crianças de segmentos sociais diferentes ${ }^{9}$. No jogo do "faz-de-conta”, os grupos expressam as realidades em que elas convivem. Ambos os grupos de crianças brincam. Entretanto cada grupo vai reproduzir, de forma, distinta, o "mundo dos adultos" em que convive.

Corsaro (2002) sugere que a relação entre as gerações (crianças x adultos) é melhor compreendida quando se analisa a infância do ponto de vista estrutural. Para isso, é preciso buscar os estudos do sociólogo dinamarquês Jens Qvortrup (2010), que oferece esse olhar para a infância, enquadrando-a como uma categoria estrutural permanente. $O$ sociólogo também defende que a criança não é um ser que é segregado da sociedade, só vindo a integrá-la quando adulto. Segundo ele, a infância faz parte da sociedade, sendo mais bem compreendida como uma categoria estrutural permanente na sociedade pela qual, a todo o momento, chegam novas crianças, e deixam de fazer parte desta categoria aquelas que já não são mais crianças.

A infância existe enquanto um espaço social para receber qualquer criança nascida e para inclú́-la - para o que der e vier - por todo o período da sua infância. Quando essa criança crescer e se tornar um adulto, a sua infância terá chegado ao fim, mas enquanto categoria a infância não desaparece, ao contrário, continua a existir para receber novas gerações de crianças. (QVORTRUP, 2010, p. 637)

Esta categoria sofre modificações ao longo da história e, ao mesmo tempo, mantém-se distinguível de outras categorias geracionais, bem como está sujeita ao impacto dos parâmetros sociais. Nas palavras de Müller e Hassen (2009), "para a sociedade, a infância é uma forma estrutural permanente, mesmo que seus membros e concepções sempre mudem".

O entendimento da infância enquanto categoria presente e permanente na estrutura social afirma que as crianças, enquanto grupo, possuem uma identidade comum, ou seja, a infância constitui uma forma estrutural particular, definida não pelas características individuais das crianças, mas por suas demandas comuns. A partir da concepção de infância enquanto forma estrutural, é possível compará-la a outras formas de estratificação social. Portanto, a afirmação da infância

\footnotetext{
${ }^{9}$ Para mais detalhes, ver Corsaro (2002).
} 
enquanto categoria estrutural permite identificar as características comuns às crianças. (DIAS, 2012, p. 70)

Para Qvortrup (2010), as infâncias se diferenciam, ao longo do tempo, ("dimensão vertical da infância”, o “desenvolvimento da infância”), bem como a infância é diferente da fase adulta, que é diferente da velhice ("dimensão horizontal”, "infância enquanto categoria geracional”).

Segundo Corsaro (2002, p. 52),

a abordagem de Qvortrup à infância como um fenômeno social e sua ênfase nas crianças como coconstrutoras ativas de seus mundos sociais refletem uma mudança importante nas visões individualistas de socialização nas quais cada criança internaliza habilidades e conhecimentos adultos. Sua abordagem leva a uma melhor compreensão do lugar, interesse e importância na produção e manutenção cultural das crianças.

Entende-se por cultura das crianças "um conjunto estável de actividades ou rotinas, artefactos, valores e ideias que as crianças produzem e partilham em interacção com os seus pares" (CORSARO; EDER,1990 apud SARMENTO, 2005, p. 373). Segundo Sarmento (2005), tais atividades são fruto, em termos culturais, do que os adultos produzem para as crianças e do que elas próprias produzem ao interagirem entre seus pares e com os adultos. Sarmento conceitua "culturas da infância" como a "capacidade das crianças em construírem de forma sistematizada modos de significação do mundo e de acção intencional, que são distintos dos modos adultos de significação e acção" (SARMENTO, 2003, p. 3-4).

O autor salienta, ainda, que tais culturas sofrem influência da coletividade na qual está inserida a criança, sendo a interação infância x sociedade marcada por "relações desiguais de classe, de gênero e de etnia" (SARMENTO, 2003, p. 8).

\section{Considerações finais}

A criança, ao longo do tempo, foi percebida pelos adultos de diferentes formas: desde um adulto em miniatura, que não demandava tratamento especial até um ser revestido de peculiaridades e necessidades a serem supridas. 
Numa mesma época, percebemos que coexistiram/coexistem diferentes olhares sobre a infância. Enquanto nas famílias abastadas da Idade Média, as crianças recebiam mimos, nas famílias de camponeses, as crianças auxiliavam os familiares nos afazeres domésticos ou logo cedo aprendiam algum ofício. Nos dias de hoje, essa diferenciação ainda existe. A criança que vive em um nobre bairro de uma cidade não é tratada da mesma forma que uma criança da periferia, que vive de vender doces em um semáforo.

Ao se pesquisar o campo da infância, precisamos dispor de um olhar multidisciplinar, levando em consideração a diversidade de perspectivas contidas nesta categoria. Ter em vista tal consciência possibilitará uma melhor apreensão do universo infantil.

\section{Referências}

ALCÂNTARA, Pedro de. Introdução ao estudo da pediatria. In: MARCONDES, Eduardo (Org.). Pediatria básica. 9. ed. São Paulo: Sarvier, 2002, v. 1, p. 3-9.

ALTMAN, Raquel Zumbano. Brincando na história. In: DEL PRIORE, Mary (Org.). História das crianças no Brasil. 7. ed. São Paulo: Contexto, 2013, p. 231-258.

ARIÈS, Phillippe. História social da criança e da família. 3. ed. Rio de Janeiro: LTC, 2012.

CHALLOUB, Sidney. Cortiços. In: CHALLOUB, Sidney. Cidade febril: cortiços e epidemias na Corte imperial. São Paulo: Companhia das Letras, 1996, p. 15-59.

CHAMBOULEYRON, Rafael. Jesuítas e as crianças no Brasil quinhentista. In: DEL PRIORE, Mary (Org.). História das crianças no Brasil. 7. ed. São Paulo: Contexto, 2013, p. 55-83.

CORSARO, William A. A reprodução interpretativa no brincar ao faz de conta das crianças. Educação, Sociedade \& Culturas, n. 17, p. 113-134, 2002.

CORSARO, William A. Sociologia da infância. 2. ed. Porto Alegre: Artmed, 2011.

DELGADO, Ana Cristina Coll. Estudos socioantropológicos da infância no Brasil: caminhos, problematizações e diálogos. In: MARTINS FILHO, Altino J.; PRADO, Patrícia, D. (Orgs.).Das pesquisas com crianças à complexidade da infância. Campinas: Autores Associados, 2011, p. 181-210.

DEL PRIORE, Mary. História das crianças no Brasil. 7. ed. São Paulo: Contexto, 2013. 
DIAS, Sabrina da Costa. A emergência da sociologia da infância: rupturas conceituais no campo da sociologia e os paradoxos da infância na contemporaneidade. Veras, São Paulo, v. 2, n. 1, p. 63-80, 2012.

FURLANETTO, Beatriz Helena. Da infância sem valor à infância de direitos: diferentes construções conceituais de infância ao longo do tempo histórico. In: CONGRESSO NACIONAL DE EDUCAÇÃO (EDUCERE), 8, Curitiba, 2008. Anais... Curitiba: Champagnat, 2008. Disponível em: <http:// www.pucpr.br/eventos/educere/Educere 2008/anais/pdf/892_632.pdf>. Acesso em: 09/07/2014.

GÓES, José Roberto de; FLORENTINO, Manolo. Crianças escravas, crianças dos escravos. In: DEL PRIORE, Mary (Org.). História das crianças no Brasil. 7. ed. São Paulo: Contexto, 2013, p. 177-191.

GÓIS JÚNIOR, Edivaldo. Movimento higienista: na história da vida privada no Brasil: do homogêneo ao heterogêneo. Conscientiae Saúde. São Paulo, n. 1, p. 47-52 , 2002.

KLEIN, Lígia Regina. Cadê a criança do Ariès que estava aqui? A fábrica comeu... In: SEMINÁRIO NACIONAL DE ESTUDOS E PESQUISAS “HISTÓRIA, SOCIEDADE E EDUCAÇÃO NO BRASIL”, 9, João Pessoa, 2012. Anais... João Pessoa: UFPB, 2012. ISBN 978-85-7745551-5.

LOPES, Karina Rizek; MENDES, Roseana Pereira; FARIA, Vitória Líbia Barreto de. (Orgs.). Livro de estudo. Brasília, 2005. 32 p. (Coleção PROINFANTIL; Unidade 3).

MARCONDES, Eduardo. Ser puericultor. In: MARCONDES, Eduardo. Pediatria básica. $9^{\mathrm{a}}$ ed. São Paulo: Sarvier, 2002, v. 1, p. 117-124.

MARTINS, Ana Paula Vosne. "Vamos criar seu filho": os médicos puericultores e a pedagogia materna no século XX. História, ciências e saúde - Manguinhos, Rio de Janeiro, v. 15, n. 1, p. 135-154, jan./mar., 2008.

MARTINS FILHO, Altino José; PRADO, Patrícia Dias (Orgs.). Das pesquisas com crianças à complexidade da infância. Campinas: Autores Associados, 2011.

MAUAD, Ana Maria. A vida das crianças de elite durante o império. In: DEL PRIORE, Mary (Org.). História das crianças no Brasil. 7. ed. São Paulo: Contexto, 2013, p. 137-176.

MÜLLER, Fernanda; HASSEN, Maria de Nazareth Agra. A infância pesquisada. Psicologia USP, São Paulo, n. 20, v. 3, p. 465-480, jul./set. 2009.

PASSETTI, Edson. Crianças carentes e políticas públicas. In: DEL PRIORE, Mary (Org.).

História das crianças no Brasil. 7. ed. São Paulo: Contexto, 2013, p. 347-375.

PEREIRA, Júnia Sales. História da pediatria no Brasil: de final do século XIX a meados do século XX. 2006, 211 f. Tese (Doutorado em História) - UFMG. Faculdade de Filosofia e Ciências Humanas, Belo Horizonte, 2006. 
QVORTRUP, Jens. A infância enquanto categoria estrutural. Educação e Pesquisa. São Paulo, v. 36, n. 2, p. 631-643, maio/ago., 2010.

RAMOS, Fábio Pestana. A história trágico-marítima das crianças nas embarcações portuguesas do século XVI. In: DEL PRIORE, Mary (Org.). História das crianças no Brasil. 7. ed. São Paulo: Contexto, 2013, p. 19-54.

RIVORÊDO, Carlos Roberto Soares Freire de. Pediatria: medicina para crianças? Saúde e Sociedade, São Paulo, v. 7, n. 2, p. 33-45, 1998.

SANTOS, João Diógenes Ferreira dos. As diferentes concepções de infância e adolescência na trajetória histórica do Brasil. Revista HISTEDBR [On-line], Campinas, n. 28, p. 224-238, 2007. Disponível em:

<www.histedbr.fe.unicamp.br/revista/edicoes/28/art15_28.pdf >. Acesso em: 09/07/2014

SARMENTO, Manuel Jacinto. Imaginário e culturas da infância. Cadernos de Educação, Pelotas, v. 12, n. 21, p. 51-59, 2003. Disponível em:

<http://www.titosena.faed.udesc.br/Arquivos/Artigos_infancia/Cultura\%2ona\%2olnfancia.pdf>. Acesso em: 19/06/2014.

SARMENTO, Manuel Jacinto. Gerações e alteridade: interrogações a partir da sociologia da infância. Educação \& Sociedade, Campinas, v. 26, n. 91, p. 361-378, maio/ago., 2005.

SOCIEDADE BRASILEIRA DE PEDIATRIA. Disponível em:

<http://www.sbp.com.br/institucional/academia-brasileira-de-pediatria/patronos-etitulares/pedro-de-alcantara-marcondes-machado/>. Acesso em: 11/06/14.

SOUSA, Débora da Silva; OLIVEIRA, Iranilson Buriti. De estrela a sementeira: o pediatra e sua pena prescrevendo as representações da infância no I Congresso Brasileiro de Proteção à Infância. In: SIMPÓSIO NACIONAL DE HISTÓRIA CULTURAL ESCRITAS DA HISTÓRIA: VER - SENTIR - NARRAR, 6, Teresina, 2012. Anais... Uberlândia: GT Nacional de História Cultural, 2012.

Universidade do Estado de Santa Catarina - UDESC Programa de Pós-Graduação em Educação - PPGE Revista Linhas 